\title{
Biotransformation of nonylphenol ethoxylates during sewage treatment under anaerobic and aerobic conditions
}

\author{
ZHANG Jing, YANG Min*, ZHANG Yu, CHEN Meixue \\ State Key Laboratory of Environmental Aquatic Chemistry, Research Center for Eco-Environmental Sciences, Chinese Academy of Sciences, \\ Beijing 100085, China. E-mail: zhangjing@mails.gucas.ac.cn
}

Received 3 April 2007; revised 18 April 2007; accepted 18 May 2007

\begin{abstract}
Biotransformation of nonylphenol ethoxylates (NPEOs) during continuous anaerobic sewage treatment was compared with the aerobic treatment of sewage spiked with $23 \mu \mathrm{mol} / \mathrm{L}$ technical NPEOs over a period of $90 \mathrm{~d}$. Immediate degradation of NPEOs was observed under both anaerobic and aerobic conditions, indicating that the enzymes and bacteria required for NPEO degradation existed abundantly in both aerobic and anaerobic sludge. Both treatments achieved high removal $(>92 \%)$ of the spiked NPEO9 mixture. Liquid chromatography-mass spectrometry (LC-MS) analysis showed that short-chain NPEOs (NPEO1-NPEO3) accumulated in anaerobic $(2.01-2.56 \mu \mathrm{mol} / \mathrm{L})$ and aerobic $(1.62-2.03 \mu \mathrm{mol} / \mathrm{L})$ effluents, with nonylphenol (NP) $(0.24-0.31 \mu \mathrm{mol} / \mathrm{L})$ as another group of metabolites in the anaerobic effluent, and nonylphenoxy carboxylates (NPECs) $(2.79-3.30 \mu \mathrm{mol} / \mathrm{L})$ in the aerobic effluent. Significant accumulation of NP in the anaerobic sludge and NPEO1-3 in the sludge of two reactors was observed. These results indicated that it was difficult to control these harmful metabolites in the conventional treatment processes. Denaturing gradient gel electrophoresis profiles of sludge samples support the speculation that the NPEO degradation bacteria might be the dominant indigenous species.
\end{abstract}

Key words: biodegradation; nonylphenol; nonylphenol ethoxylate; nonylphenoxy carboxylates; sewage treatment

\section{Introduction}

The environmental fate of nonylphenol ethoxylates (NPEOs), one class of important nonionic industrial surfactants, has received wide attention because some of their degradation products, such as nonylphenol (NP), act as the mimic hormones to aquatic organisms (White et al., 1994). The surfactants have been found existing widely in wastewater, sludge, and surface water, even drinking water, together with many of its metabolites, raising public concerns over their ecological effects (Blackburn and Waldock, 1995; Wenzel et al., 2004).

In view of the fact that most NPEOs flow into sewage treatment plants (STPs) after use, sewage treatment becomes the key step that prevents the NPEOs and their metabolites from being discharged into water environments. The behaviors of NPEOs and their intermediate degradation products in STPs have been investigated by many researchers. NPEOs can be efficiently eliminated in well-functioning wastewater treatment plants. However, more toxic degradation products such as NP, nonylphenol mono-to triethoxylates (NPEO1-3), and nonylphenoxy carboxlates (NPECs) have been detected in the effluents of many STPs throughout the world (Ying et al., 2002).

Although many investigations have been conducted, there are few reports documenting the conditions for the

\footnotetext{
* Corresponding author. E-mail: yangmin@ @rcees.ac.cn.
}

degradation of NPEOs and their intermediate products in the continuous biological treatment, especially for anaerobic processes (Ejlertsson et al., 1999). According to previous studies (Giger et al., 1984), the most persistent metabolite of NPEOs, endocrine disruptor NP, is formed under anaerobic conditions. As the anaerobic process is recognized as an effective technology for the pretreatment of high-strength industrial wastewater, for example, the pulp and paper mills wastewater, in which amounts of NPEO surfactant is commonly found (Buzzini and Pires, 2002; Hawrelak et al., 1999), it is therefore of great importance to understand the biotransformation behavior of NPEOs under anaerobic conditions.

In this study, an anaerobic reactor seeded with digester sludge was conducted to treat the NPEO-spiked sewage during continuous processes. In comparison, an aerobic reactor inoculated with activated sludge was operated simultaneously utilizing the same influent. The degradation of a commercial NPEO mixture during continuous anaerobic and aerobic treatments was qualitatively determined using Liquid chromatography-electrospray mass spectrometry (LC-ES-MS). The effect of hydraulic residence time (HRT) on the removal of NPEO oligomers, in relation to chain length and distribution was investigated. Changes in bacterial community structures were evaluated using a denaturing gradient gel electrophoresis (DGGE), to observe the impact of spiked surfactants on bacterial 
community shifts in two reactors.

\section{Materials and methods}

Pure NPEOs and NPECs mixture standards (with EO chain lengths from 0 to 9 , corresponding from NPEC1 to NPEC10) were obtained from Hayashi Pure Chemicals (Osaka, Japan). A nonionic surfactant (NPEO9 mixture, the most widely-used technical grade of NPEOs with an average EO unit of 9) spiked to municipal wastewater was provided by Shanghai Auxiliary Manufactory (Shanghai, China). All organic solvents (HPLC grade) were obtained from the Fisher Company (USA). Ultrapure water (18.2 M $\Omega$ ) was acquired using a PURIC-MXII apparatus (Organo Co., Japan). Ammonium acetate of HPLC grade was purchased from Fluka (Steinheim, Germany), and Oasis HLB (60 mg, $3 \mathrm{ml}$ ) extraction cartridges were from Waters (USA). Fig.1 has visualized general structures of NPEOs and their major degradation products.
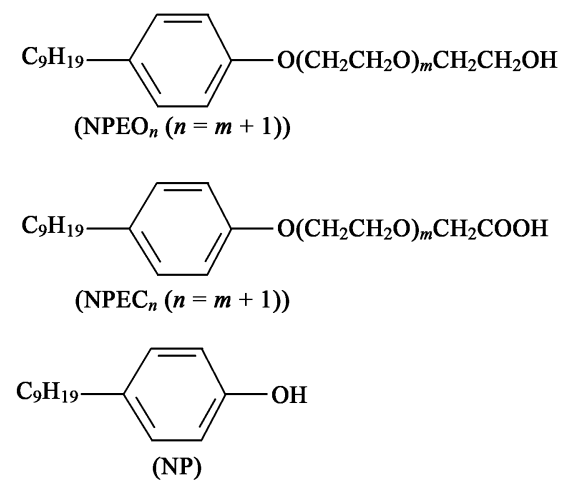

Fig. 1 Structures and acronyms of the nonylphenolic compounds.

\subsection{Reactors and operating conditions}

This laboratory-scale study was performed using two different reactor designs. One was an upflow anaerobic sludge blanket (UASB) system and the other was a conventional activated sludge system. Both reactors had a working volume of 4.0 L. The anaerobic reactor and aerobic reactor were seeded with digester sludge and the activated sludge was obtained from a sewage treatment plant in Beijing, respectively, and the starting, mixed liquor suspended solids (MLSS) were 5.1 and $2.1 \mathrm{~g} / \mathrm{L}$, respectively. Biogas from the UASB reactor was collected in a water displacement system. Raw sewage $(\mathrm{pH} 7.4 \pm 0.2$, chemical oxygen demand $\left.\left(\mathrm{COD}_{\mathrm{Cr}}\right) 232 \pm 15 \mathrm{mg} / \mathrm{L}\right)$ was taken from a nearby domestic sewer. The spiked wastewater was prepared every $12 \mathrm{~h}$ to avoid the biodegradation of NPEOs in the matrix, and the concentration of the amended NPEO9 mixture was $23 \mu \mathrm{mol} / \mathrm{L}(15 \mathrm{mg} / \mathrm{L})$. Given that the sum of $\mathrm{NP}$, NPEOs, and NPECs in raw sewage was always lower than $0.03 \mu \mathrm{g} / \mathrm{L}$, these compounds in raw water could be neglected. Before spiking with the surfactant, raw sewage was continuously supplied to the two reactors at an HRT of $5.5 \mathrm{~h}$ for two months, which corresponded to stage 0 in Table 1. Then the surfactant-spiked sewage was fed into the reactors under the same HRT for one month (stage 1). The HRT was increased to $8.7 \mathrm{~h}$ (stage 2 , after it was kept for one month), and finally to $15.8 \mathrm{~h}$ (stage 3 , after it was kept for one month). The $\mathrm{pH}$ values of the effluent from two reactors varied between 7.1 and 7.5, whereas, the oxidation-reduction potential (ORP) in the anaerobic system was at a level of $-350 \pm 20 \mathrm{mV}$ throughout the experimental period.

\subsection{Sample treatment}

Aqueous samples from the inlet and outlet of the bioreactors were taken twice a week, after the whole systems were stably operated at a given condition for $7 \mathrm{~d}$, unless stated otherwise. Formaldehyde of $1 \%$ (v/v) was added to the samples for preservation. After it was filtered over $0.45-\mu \mathrm{m}$ glass fibers, the inlet samples were analyzed without further treatment. Solid-phase extraction (SPE) of the outlet samples was performed on an Oasis HLB cartridge which had been conditioned sequentially with

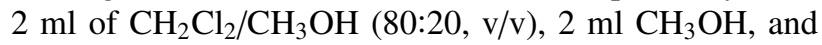
$2 \mathrm{ml}$ water. Samples of $10 \mathrm{ml}$ were extracted at a flow rate of $1 \mathrm{ml} / \mathrm{min}$, and then the cartridge was dried by passing a gentle nitrogen stream for about $20 \mathrm{~min}$ and washed with $2 \mathrm{ml}$ hexane. The analytes were eluted with $5 \mathrm{ml} \mathrm{CH} \mathrm{Cl}_{2} / \mathrm{CH}_{3} \mathrm{OH}$ (80:20, v/v). Then, the eluent was concentrated to dryness under a gentle nitrogen stream, and then $1 \mathrm{ml}$ methanol was added. The recoveries for NP, NPEOs, and NPECs $(1<\mathrm{s}<10)$ ranged from $74.3 \%$ to $98.4 \%$.

Sludge samples of $5 \mathrm{ml}$ collected from the anaerobic (middle of the column) and aerobic system at each stage were centrifuged at $5000 \times g$ for $5 \mathrm{~min}$, respectively. Concentrated sludge of $0.1 \mathrm{~g}$ was prepared for DNA extraction (mentioned a little later in the text). The procedure proposed by Langford et al. (1999) for the extraction of nonylphenolic compounds is briefly described herewith. After the addition of $2 \mathrm{~g}$ of sodium sulfate, oven dried, extraction of the sludge was carried out by shaker extraction, for $1 \mathrm{~h}$ each, with $5 \mathrm{ml}$ ethyl acetate, twice, and finally with $5 \mathrm{ml}$ dichloromethane. Extracts were combined and reduced to approximately $1 \mathrm{ml}$ under nitrogen, and then redissolved in $200 \mathrm{ml}$ pure water. The resulted solution was

Table 1 Operation conditions and performance of two reactors

\begin{tabular}{|c|c|c|c|c|c|c|c|c|}
\hline \multirow[t]{2}{*}{ Parameter } & \multicolumn{4}{|c|}{ Anaerobic treatment } & \multicolumn{4}{|c|}{ Aerobic treatment } \\
\hline & Stage 0 & Stage 1 & Stage 2 & Stage 3 & Stage 0 & Stage 1 & Stage 2 & Stage 3 \\
\hline COD removal (\%) & $56.8 \pm 6.5$ & $56.9 \pm 5.9$ & $60.1 \pm 4.2$ & $59.8 \pm 5.4$ & $79.7 \pm 4.9$ & $78.2 \pm 6.7$ & $81.2 \pm 4.5$ & $82.3 \pm 2.1$ \\
\hline $\operatorname{MLSS}(\mathrm{g} / \mathrm{L})$ & $5.1 \pm 0.1$ & $5.0 \pm 0.1$ & $5.1 \pm 0.1$ & $5.1 \pm 0.1$ & $2.2 \pm 0.2$ & $1.8 \pm 0.3$ & $2.0 \pm 0.2$ & $2.1 \pm 0.2$ \\
\hline $\mathrm{DO}(\mathrm{mg} / \mathrm{L})$ & 0 & 0 & 0 & 0 & $>3.5$ & $>3.5$ & $>3.5$ & $>3.5$ \\
\hline HRT (h) & 5.5 & 5.5 & 8.7 & 15.8 & 5.5 & 5.5 & 8.7 & 15.8 \\
\hline Sludge age (d) & 11 & 11 & 17 & 31 & 7 & 5 & 9 & 17 \\
\hline
\end{tabular}


concentrated and cleaned up by the SPE method mentioned above.

\subsection{Analytical methodology}

A HPLC method developed by Shao et al. (2001) was used to detect the EO chain distribution of NPEOs during the treatment. Identification and quantification of NPEOs and their metabolites (NP and NPECs) were performed on a liquid chromatograph (Alliance 2695, Waters, USA) coupled with an electrospray mass spectrometer (ZQ 4000, Micromass, UK). A Waters Symmetry ShieldTM RP18 column $(150 \mathrm{~mm} \times 2.1 \mathrm{~mm}$ i.d., $5 \mu \mathrm{m})$ was used for the separation. The two mobile phases were (A) water containing $5 \mathrm{mmol} / \mathrm{L}$ ammonium acetate and (B) pure methanol. At a flow rate of $0.2 \mathrm{ml} / \mathrm{min}$, a gradient elution was performed starting with $30 \% \mathrm{~B}$ and kept for $5 \mathrm{~min}$. Then, phase $\mathrm{B}$ increased linearly in $7 \mathrm{~min}$ to $85 \%$ and kept for $10 \mathrm{~min}$. Then phase B further increased to $97 \%$ in $2 \mathrm{~min}$, which was kept constant for $8 \mathrm{~min}$. Finally, the composition was brought back to the initial conditions and equilibrated for $9 \mathrm{~min}$. For identification and determination, the MS detector was performed with optimal parameters and conditions (Hayashi et al., 2005). A linear five-point calibration curve was used for quantification. Furthermore, dicarboxylated metabolites (CAPECs) were investigated using the methods proposed by Di Corcia et al. (2000).

COD, dissolved oxygen (DO), MLSS, ORP, and the sludge volumetric index (SVI) were measured in accordance with the Standard Method for Examination of Water and Wastewater (AWWA, 1998).

\subsection{Amplification of 16S rDNA and DGGE}

For every concentrated sludge sample, the DNA was extracted and purified by a Unix-10 column DNA Preps Kit (Sangon, China) according to the manufacturer's instructions. The V3 region of the $16 \mathrm{~S}$ rDNA gene was amplified from the genomic DNA, and provided for DGGE analysis on a Bio-Rad Decode system (Muyzer et al., 1993). The PCR-DGGE was performed thrice to ensure consistent results. Some bands were excised manually from gels, after which they were sequenced at GeneBank BioTechnologies Co. Ltd. (Shanghai, China). The obtained nucleotide sequences have been deposited in the GenBank database under accession number DQ432626-DQ432634.

\section{Results and discussion}

\subsection{Reactors performance}

After a stabilization period of two months, both reactors exhibited a constant performance. The reactors' performance under stable conditions is summarized in Table 1. The anaerobic system achieved a COD removal of about $60 \%$, whereas, the aerobic one exhibited a higher value $(>75 \%)$. Spiking the surfactant into the sewage did not produce perceptible effects on the carbonaceous removal capacity of the two reactors. However, MLSS in the aerobic system decreased quickly from 2.3 to 1.5 $\mathrm{g} / \mathrm{L}$ after NPEOs spiked into the influent, resulting in the increase of SVI from 95 to $167 \mathrm{ml} / \mathrm{g}$. This phenomenon was attributed to the structural change of activated sludge flocs caused by the influence of the surfactant (Lozada et al., 2004). However, the SVI in the aerobic reactor decreased gradually to a relatively constant value of 119 $\pm 6.5 \mathrm{ml} / \mathrm{g}$ two weeks later.

\subsection{Biodegradation of NPEOs in the reactors}

Figure 2 shows the HPLC chromatograms of the influent (a) and the effluents from the aerobic (b) and anaerobic (c) systems on day 2, after NPEO spiking. Chromatogram (a) demonstrates a typical distribution of the NPEO9 mixture, containing NPEO oligomers with an EO group ranging from 4 to 19 units. Although a similar peak pattern can be identified in chromatogram (c) at a significantly lower strength, with the concomitant appearance of NPEO1 and NPEO2 (peak at $7.2 \mathrm{~min}$ ), chromatogram (b) demonstrates a completely different peak pattern. As will be discussed a little later, this difference is attributed to the formation of NPECs in the aerobic system. It is clear that significant degradation of NPEOs occurred in the two systems after the beginning of surfactant spiking, which indicates that biodegradation of the compounds under both anaerobic and aerobic conditions do not require acclimation of sludge. That is to say, the enzyme and bacteria required for NPEOs degradation exist in both anaerobic and aerobic systems. Similar results in an aerobic batch system have also been observed by other researchers (Langford et al., 2005).

Distribution of metabolites in the effluent at different operational stages is shown in Fig.3 together with the residual concentration of the spiked NPEO9 mixture. The average removals of the spiked surfactants under anaerobic and aerobic treatment in stage 1 were $92.2 \%$ and $98.3 \%$, respectively, indicating faster degradation under aerobic conditions. With the increase of HRT, the removal of NPEOs increased slightly in both anaerobic and aerobic systems. The main metabolites under the anaerobic treatment were NPEO1-3 and NP, whereas, those under the aerobic treatment were NPECs and NPEO1-3. NPECs were not detected in the anaerobic effluents and no NP

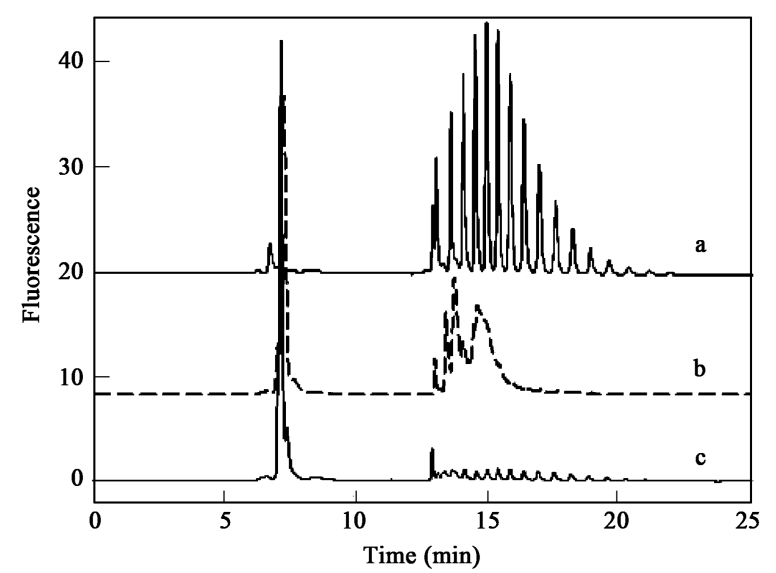

Fig. 2 HPLC chromatograms of influent (a) aerobic effluent and (b) anaerobic effluent (c) at the startup stage. 

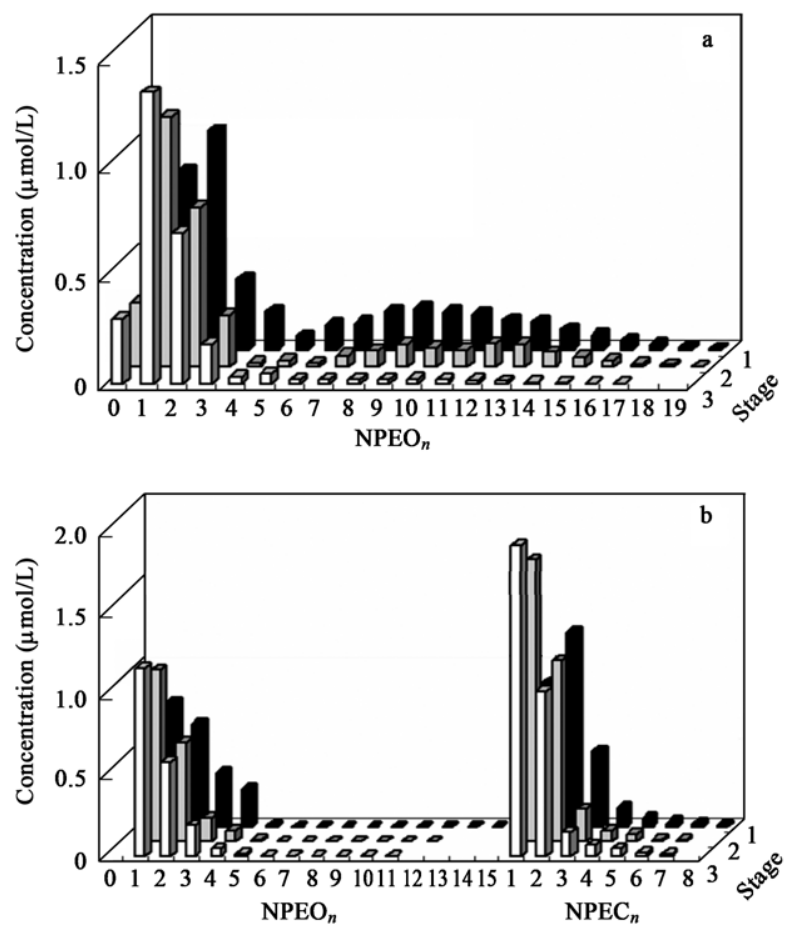

Fig. 3 Distribution of metabolite homolog in the effluents at different stages. (a) NPEOs and NP $(n=0)$ in anaerobic effluent; (b) NPEOs and NPECs in aerobic effluent. Each concentration had a mean value of four times of the sampling and the relative standard deviations were below $13.7 \%$.

was detected in the aerobic ones, which was in accordance with the generally accepted NPEO degradation pathways (Ahel et al., 1994). Frequent reports about the existence of NP in the effluents of many sewage treatment plants might be attributed to the formation of NP during sewage transportation or in some anaerobic zones of the treatment processes.

For the anaerobic effluent, the long EO chain oligomers disappeared gradually with the increase of HRT. NP and NPEO1-3 in the effluent increased respectively from 0.24 to $0.31 \mu \mathrm{mol} / \mathrm{L}$ and from 2.01 to $2.56 \mu \mathrm{mol} / \mathrm{L}$, with the increase of HRT from 5.5 to $15.8 \mathrm{~h}$. NP formed under anaerobic conditions was about one-eighth of NPEO1-3. It was clear that elongation of the anaerobic treatment did not result in the removal of the harmful degradation products.

For the aerobic treatment, the concentration of NPECs and NPEO1-3 in the effluents increased from 2.79 to
$3.30 \mu \mathrm{mol} / \mathrm{L}$ and 1.62 to $2.03 \mu \mathrm{mol} / \mathrm{L}$ with the increase of HRT from 5.5 to $15.8 \mathrm{~h}$, indicating that elongation of the aerobic treatment did not result in the removal of the harmful degradation products either. It should be noted that the concentration of NPECs was even higher than that of NPEO1-3, which was different from most of the reported data (Di Corcia and Sampert, 1994; Fujita et al., 2000). NPECs with EO chains higher than eight were not found, which might be a result of the rapid degradation of the long chain NPECs (Jonkers et al., 2001). CAPECs were regarded as the dominant metabolites in the aerobic treatment systems, in recent studies. However, CAPECs were not found in the aerobic effluent throughout the whole experiment. As Jonkers et al. (2001) and Di Corcia et al. (1998) reported, CAPECs started to accumulate after the short NPECs formed during the biotransformation of NPEOs. HRTs $(5.5-15.8 \mathrm{~h})$ in the study might be not enough for the formation and accumulation of CAPECs. Generally speaking, NP had a much higher estrogenisity than NPECs (Routledge and Sumpter, 1996; Metcalfe et al., 2001). Nevertheless, Jobling et al. (1996) found that NPEC1 had estrogenic potencies approximately similar to NP and short-chain NPEOs. Regarding the prevailing existence under the aerobic condition, the environmental fate of the NPECs should be concentrated on in future studies.

NPEO biodegradation products are more lipophilic than their parent compounds and tend to be adsorbed on sludge and sediments (Thiele et al., 1997). Concentrations of the metabolites in the sludge of the two reactors have been determined, and the results are shown in Fig.4. Significant accumulation of NP $(15.61 \pm 1.48 \mu \mathrm{mol} / \mathrm{g})$ and NPEO1-3 $(13.01 \pm 0.77 \mu \mathrm{mol} / \mathrm{g})$ in anaerobic sludge and NPEO1-2 (19.84 $\pm 3.27 \mu \mathrm{mol} / \mathrm{g})$ in aerobic sludge has been observed, respectively. Although NP is not detected in the aerobic effluents, a level of 0.23 and $0.35 \mu \mathrm{mol} / \mathrm{g}$ was found in the aerobic sludge in stage 2 and stage 3, respectively, which might be attributed to the existence of anaerobic zones in the reactor. The relatively low NPECs concentrations in aerobic sludge were because of their relatively high hydrophilicity.

Hung et al. (2004) has reported that the sorption of nonylphenolic compounds (NP, NPEO1-2, and NPEC1-3) onto activated sludge requires no more than $12 \mathrm{~h}$ to reach equilibrium. It is therefore reasonable to speculate that the
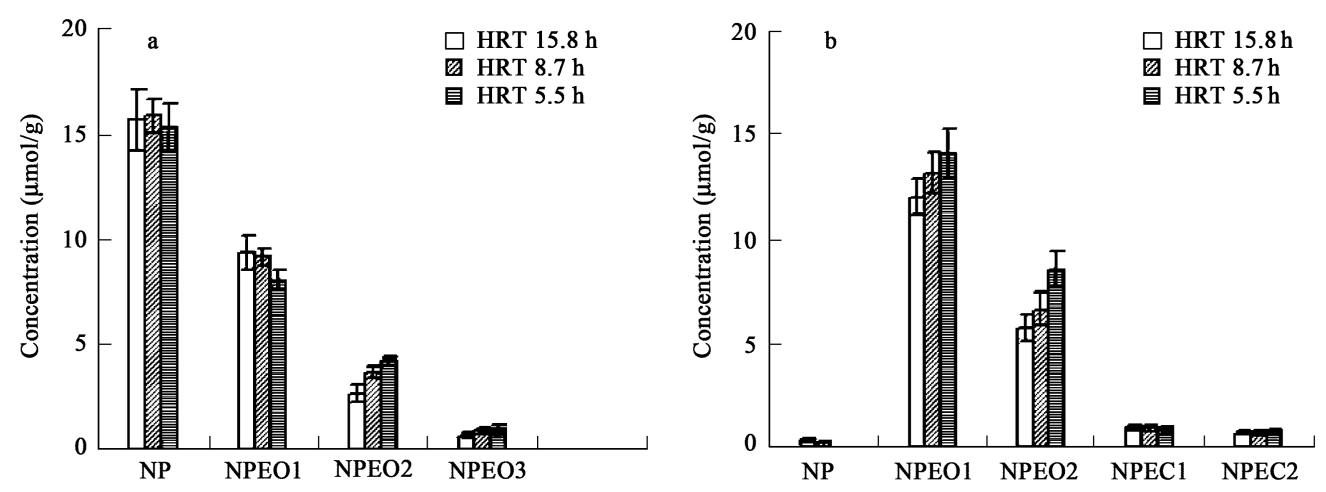

Fig. 4 Concentrations of metabolites in the sludge of (a) anaerobic system and (b) aerobic system at different stages. 
adsorption of all the intermediates on sludge had already reached equilibrium, before sampling, as the reactors had been operated continuously for two weeks in each stage without sludge purging. According to this assumption, the average distribution factors could be given as the ratio of the adsorbed to the dissolved chemicals. The average distribution factors for NPEO1, NPEO2, and NPEO3 in the anaerobic system were 9195,5693 , and $4674 \mathrm{~L} / \mathrm{kg}$, respectively, and those in the aerobic system were 9430 , 8360 , and $8089 \mathrm{~L} / \mathrm{kg}$, respectively. Moreover, the average distribution factors for NPEC1 $(543 \mathrm{~L} / \mathrm{kg})$ and NPEC2 $(610 \mathrm{~L} / \mathrm{kg})$ were one order smaller than those for short NPEOs. These results were compatible with the previous report (Hung et al. 2004). The distribution factor for NP in the anaerobic reactor was significantly high $(51920 \mathrm{~L} / \mathrm{kg})$, which was compatible with that $(57200 \mathrm{~L} / \mathrm{kg})$ reported by Okayasu et al. (2005), who studied NPEO degradation in an aeration tank, with the DO level controlled below 0.5 $\mathrm{mg} / \mathrm{L}$. A high distribution factor indicated that the anaerobic sludge for the NPEOs-bearing wastewater treatment should be disposed properly.

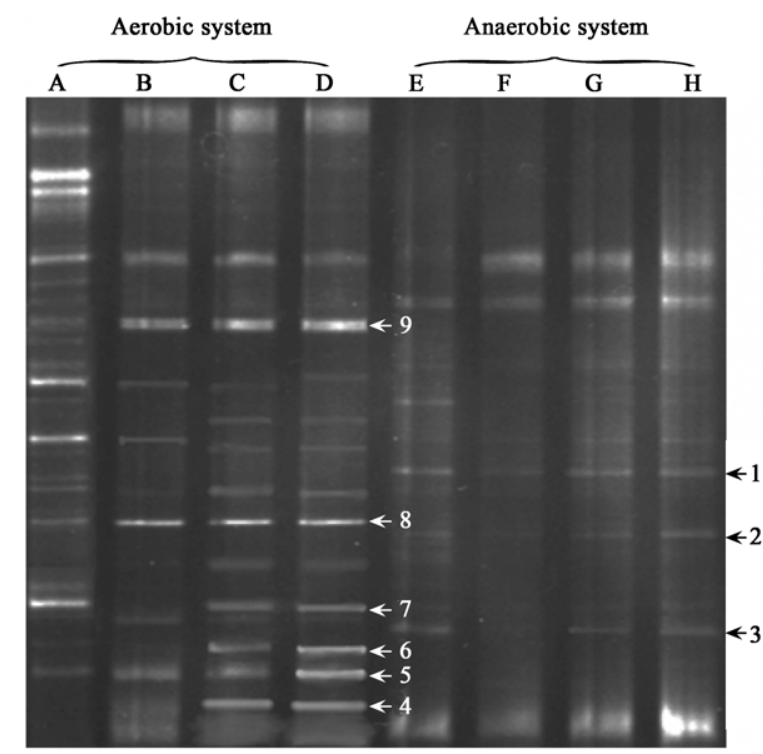

Fig. 5 DGGE profiles of bacterial communities in anaerobic and aerobic reactors. (A-D) aerobic system; (E-H) anaerobic system. (A, E) $0 \mathrm{~d}$ corresponding to the sludge before NPEOs were amended; $(\mathrm{B}, \mathrm{F}) 15 \mathrm{~d}$ corresponding to stage $1 ;(\mathrm{C}, \mathrm{G}) 45 \mathrm{~d}$ corresponding to stage 2; (D, H), 75 d corresponding to stage 3 . Numbers $1-9$ were sequenced bands.

\subsection{DGGE analysis of bacterial community structures}

Figure 5 shows the DGGE profiles of the two systems. The band number in the aerobic system decreased from a value of 22 (lane A: startup) to 12 (lane B) following the spiking of NPEOs into raw sewage. A dramatic reduction of the bacteria species number (lane A to B) in the aerobic reactor was because of the bad settleability of activated sludge caused by the spiking of the surfactant as discussed earlier. In the following two stages, the band number increased to 18 and then to 19 . A similar trend was observed in the anaerobic system. Spiking NPEOs into raw sewage resulted in a significant decrease in the bacterial species, indicating that the surfactant had a great impact on the bacterial community structures. With the prolongation of operation time, however, the bacterial community in both systems became adapted to the complex substrate composition, as indicated by the increase of band number in the last two phases. Although the DGGE profiles changed markedly during the experiment, few new bands appeared after the NPEOs were spiked into raw sewage, suggesting that NPEOs could be degraded by the existing microorganisms. This assumption was ascertained by the fact that degradation of NPEOs appeared rapidly following the spiking of NPEOs.

Albeit many bacteria being capable of degrading short NPEOs and NP being isolated from STPs (Chang et al., 2005; Fujii et al., 2001; Gabriel et al., 2005), the significant accumulation of these intermediates in the two systems indicates that these bacteria cannot exist as the dominant ones in conventional biological systems, even under a relatively long HRT.

Nucleotide sequences of bands 1 to 9 in Fig. 5 were compared to the Genbank database using BLAST. Table 2 shows that Clostridium sp., which is gram-positive bacteria with low $\mathrm{G}+\mathrm{C}$ content, and oxygen-independent Prokaryotes, were the dominant species in the anaerobic system. In the aerobic system, Proteobacteria, including $\beta$-Proteobacteria (Comamonas sp. and Comamonadaceae bacterium) and $\gamma$-Proteobacteria (Stenotrophomonas sp. and Rhodanobacter sp.), were found as the dominant species. This is in accordance with the previous reports. Proteobacteria have been observed to be dominant in activated sludge communities (Manz et al., 1994). Lozada et al. (2004) have found that the beta subclass of Proteobacteria constitutes the predominant group of bacteria in NPEO10-amended activated sludge. On the other hand, most of the isolated NPEO-degrading bacteria, such

Table 2 Phylogenetic sequence affiliation of amplified 16S rDNA gene sequences excised from DGGE gel

\begin{tabular}{|c|c|c|c|}
\hline Band & Closest BLAST match & Identity $(\%)$ & Accession number \\
\hline 1 & Uncultured bacterium & 98 & DQ432626 \\
\hline 2 & Uncultured bacterium & 100 & DQ432627 \\
\hline 3 & Uncultured Clostridium sp. & 98 & DQ432628 \\
\hline 4 & Uncultured Rhodanobacter sp. & 100 & DQ432629 \\
\hline 5 & Uncultured $\gamma$-Proteobacterium & 99 & DQ432630 \\
\hline 6 & Uncultured Comamonas sp. & 99 & DQ432631 \\
\hline 7 & Uncultured Comamonadaceae bacterium & 99 & DQ432632 \\
\hline 8 & Uncultured Stenotrophomonas sp. & 100 & DQ432633 \\
\hline 9 & Uncultured $\beta$-Proteobacterium & 99 & DQ432634 \\
\hline
\end{tabular}


as Acinetobacter, Aeromonas, Shewanella, Proteus, and Pseudomonas groups (Barberio et al., 2001; John and White, 1998), belong to $\gamma$-Proteobacteria.

\section{Conclusions}

NPEO-bearing sewage was treated by anaerobic and aerobic reactors. High removals of NPEOs were acquired in both systems, which were improved with the increase of HRT. Short-chain NPEOs accumulated significantly in both systems together with NP in the anaerobic system and NPECs in the aerobic system. Large amounts of nonylphenolic metabolites including NPEO1-3 and NP accumulated in the sludge. These harmful degradation products could not be degraded by prolongation of HRT, and further measures should be taken to control the discharge of these harmful metabolites into the environment. DGGE analysis demonstrated that microbial community structures in both reactors were significantly changed by surfactant spiking, and then recovered gradually with the operation. Most of the NPEO degradation bacteria might be indigenous dominant bacteria.

\section{Acknowledgements}

This work was supported by the National Natural Science Foundation of China (No. 50578153, 50525824, 20307010).

\section{References}

Ahel M, Giger W, Koch M, 1994. Behaviour of alkylphenol ethoxylates surfactants in the aquatic environment: I. Occurrence and transformation in sewage sludge. Water Res, 28: 1131-1142.

AWWA, 1998. Standard methods for the examination of water and wastewater. 19th ed. Washington, DC: American Public Health Association.

Barberio C, Pagliai L, Cavalieri D, Fani R, 2001. Biodiversity and horizontal gene transfer in culturable bacteria isolated from activated sludge enriched in nonylphenol ethoxylates. Res Microbiol, 152: 105-112.

Blackburn M, Waldock M, 1995. Concentrations of alkylphenols in rivers and estuaries in England and Wales. Water Res, 29: $1623-1629$.

Buzzini A P, Pires E C, 2002. Cellulose pulp mill effluent treatment in an upflow anaerobic sludge blanket reactor. Process Biochem, 38: 707-713.

Chang B V, Chiang F, Yuan S Y, 2005. Biodegradation of nonylphenol in sewage sludge. Chemosphere, 59: 16521659.

Di Corcia A, Sampert R, 1994. Monitoring aromatic surfactants and their biodegradation intermediates in raw and treated sewages by solid-phase extraction and liquid chromatography. Environ Sci Technol, 28: 850-858.

Di Corcia A, Cavallo R, Crescenzi C, Nazzari M, 2000. Occurrence and abundance of dicarboxylated metabolites of nonylphenol polyethoxylate surfactants in treated sewages. Environ Sci Technol, 34: 3914-3919.

Ejlertsson J, Nilsson M L, Kylin H, Bergman A, Karlson L, Oquist M, Svensson B H, 1999. Anaerobic degradation of nonylphenol mono- and diethoxylates in digester sludge, landfilled municipal solid waste, and landfilled sludge. Environ Sci Technol, 33: 301-306.

Fujii K, Urano N, Ushio H, Satomi M, Kimura S, 2001. Sphingomonas cloacae sp. nov., a nonylphenol-degrading bacterium isolated from wastewater of a sewage-treatment plant in Tokyo. Int J Syst Evol Microbiol, 51: 603-610.

Fujita M, Ike M, Mori K, Kaku H, Sakaguchi Y, Asano M, Maki H, 2000. Behaviour of nonylphenol ethoxylates in sewage treatment plants in Japan: Biotransformation and ecotoxicity. Water Sci Technol, 42: 23-30.

Gabriel F L P, Giger W, Guenther K, Kohler H E, 2005. Differential degradation of nonylphenol isomers by Sphingomonas xenophaga Bayram. Appl Envir Microbiol, 71: 1123-1129.

Giger W, Brunner P H, Schaffner C, 1984. 4-Nonylphenol in sewage sludge: accumulation of toxic metabolites from nonionic surfactants. Science, 225: 623-625.

Hawrelak M, Bennett E, Metcalfe C, 1999. The environmental fate of the primary degradation products of alkylphenol ethoxylate surfactants in recycled paper sludge. Chemosphere, 39: 745-752.

Hayashi S, Saito S, Kim J H, Nishimura O, Sudo R, 2005. Aerobic biodegradation behavior of nonylphenol polyethoxylates and their metabolites in the presence of organic matter. Environ Sci Technol, 39: 5626-5633.

Hung N V, Tateda M, Ike M, Fujita M, Tsunoi S, Tanaka M, 2004. Sorption of biodegradation end products of nonylphenol polyethoxylates onto activated sludge. J Environ Sci, 16: $564-569$.

Jobling S, Sheahan D, Osborne J A, Matthiessen P, Sumpter J $\mathrm{P}, 1$ 1996. Inhibition of testicular growth in rainbow trout (Oncorhynchus mykiss) exposed to estrogenic alkylphenolic chemicals. Environ Toxicol Chem, 15: 194-202.

John D M, White G F, 1998. Mechanism for biotransformation of nonylphenol polyethoxylates to xenoestrogens in Pseudomonas putida. J Bacteriol, 180: 4332-4338.

Jonkers N, Knepper T P, De Voogt P, 2001. Aerobic biodegradation studies of nonylphenol ethoxylates in river water using liquid chromatography-electrospray tandem mass spectrometry. Environ Sci Technol, 35: 335-340.

Langford K H, Scrimshaw M D, Birkett J W, Lester J N, 2005. Degradation of nonylphenolic surfactants in activated sludge batch tests. Water Res, 39: 870-876.

Lozada M, Itria R F, Figuerola E L M, Babay P A, De Tullio L A, Erijman L, 2004. Bacterial community shifts in nonylphenol polyethoxyates enriched activated sludge. Water Res, 38: 2077-2086.

Manz R, Wagner M, Amann R, Schleifer K H, 1994. In situ characterization of the microbial consortia active in two wastewater treatment plants. Water Res, 28: 1715-1723.

Metcalfe C D, Mercalfe T L, Kiparissis Y, Koenig G B, Khan C, Hughes R J, Croley T R, March R E, Potter T, 2001. Estrogenic potency of chemicals detected in sewage treatment plant effluents as determined by in vivo assays with Japanese medaka (Oryzias latioes). Environ Toxicol Chem, 20: 297-308.

Muyzer G, De Waal E C, Uitterlinden A G, 1993. Profiling of complex microbial populations by denaturing gradient gel electrophoresis analysis of polymerse chain reactionamplified genes coding for 16S rRNA. Appl Enviorn Microbiol, 59: 695-700.

Okayasu Y, Komori K, Suzuki Y, Tanaka H, Yasojima M, 2005. Nonylphenol formation from nonylphenol ethoxylates in activated sludge process. J Jan Soc Water Environ, 28: 671676. 
Routledge E J, Sumpter J P, 1996. Estrogenic activity of surfactants and some of their degradation products assessed using a recombinant yeast screen. Environ Toxicol Chem, 15: 241-248.

Shao B, Hu J Y, Yang M, 2001. Determination of nonylphnol aethoxylates and their metabolites in aquatic environment by high-performance liquid chromatography. Environ Chem, 20: 600-605.

Thiele B, Günther K, Schwuger M J, 1997. Alkylphenol ethoxylates: trace analysis and environmrntal behavior. Chem Rev, 97: $3247-3272$
Wenzel A, Bohmer W, Mller J, Rdel H, 2004. Retrospective monitoring of alkylphenols and alkylphenol monoethoxylates in aquatic biota from 1985 to 2001: Results from the German Environmental Specimen Bank. Environ Sci Technol, 38: 1654-1661.

White R, Jobling S, Hoare S A, Sumpter J P, 1994. Environmentally persistent alkylphenolic compounds are estrogenic. Endocrinology, 135: 175-182.

Ying G G, Williams B, Kookana R, 2002. Environmental fate of alkylphenols and alkylphenol ethoxylates: a review. Environ Int, 28: 215-226. 